\title{
Vasorelaxant effect of Hyptis fruticosa Salzm. ex Benth., Lamiaceae, dichloromethane extract on rat mesenteric artery
}

\author{
Ítalo J. A. Moreira, ${ }^{1}$ Maria P. N. Moreno, ${ }^{2}$ Maria F. G. Fernandes, ${ }^{2}$ João B. Fernandes, ${ }^{2}$ \\ Flávia V. Moreira, ${ }^{1}$ Angelo R. Antoniolli, ${ }^{1}$ Márcio R.V. Santos ${ }^{*}, 1$ \\ ${ }^{1}$ Departamento de Fisiologia, Universidade Federal de Sergipe, CCBS, Av Marechal Rondo s/n, Jd. Rosa Elze, \\ 49100-000 São Cristóvão-SE, Brazil \\ ${ }^{2}$ Departamento de Química, Universidade Federal de São Carlos, Rodovia Washington Luís, km 235, 1 \\ 3.565-905 São Carlos-SP, Brazil.
}

\begin{abstract}
RESUMO: "Efeito vasorelaxante do extrato diclorometano de Hyptis fruticosa Salzm. ex Benth., Lamiaceae, em artéria mesentérica de ratos". O efeito vasorelaxante do extrato diclorometano de Hyptis fruticosa Salzm. ex Benth., Lamiaceae (HFDE), em anéis isolados de artéria mesentérica de ratos foi avaliado nesse estudo. Em anéis intactos, pré-contraídos com fenilefrina $(10 \mu \mathrm{M})$, $\operatorname{HFDE}(0,1-3000 \mu \mathrm{g} / \mathrm{mL})$ induziu vasorelaxamento de maneira dependente de concentração $\left(\mathrm{E}_{\max }=\right.$ $119 \pm 14 \% ; n=6)$, o qual não foi afetado após remoção do endotélio $\left(E_{\max }=116 \pm 6 \% ; n=6\right)$, após $\mathrm{KCl} 20 \mathrm{mM}\left(\mathrm{E}_{\max }=135 \pm 9 \% ; \mathrm{n}=6\right)$ ou em anéis pré-contraídos com KCl $80 \mathrm{mM}\left(\mathrm{E}_{\max }=125 \pm 4 \%\right.$; $\mathrm{n}=6)$. Em anéis sem endotélio, HFDE (300 ou $1000 \mu \mathrm{g} / \mathrm{mL})$ inibiu as contrações induzidas por $\mathrm{CaCl}_{2}$ (inibição máxima $=25 \pm 7 \%$ e $95 \pm 1 \%$, respectivamente). Além disso, HFDE promoveu um vasorelaxamento adicional $(15 \pm 3 \% ; \mathrm{n}=7)$ sobre o relaxamento máximo de $10 \mu \mathrm{M}$ de nifedipina $(78 \pm 3 \%, \mathrm{n}=7)$. Em conclusão, HFDE induz efeito vasorelaxante através de uma via independente de endotélio, possivelmente devido à inibição do influxo de $\mathrm{Ca}^{2+}$ através de canais de $\mathrm{Ca}^{2+}$ operados por voltagem.
\end{abstract}

Unitermos: Hyptis fruticosa, extrato diclorometano, efeito vasorelaxante, artéria mesentérica, ratos.

\begin{abstract}
Vasorelaxant effect of Hyptis fruticosa dichloromethane extract (HFDE) on isolated rings of rat mesenteric artery was evaluated in this study. In intact rings, HFDE (0.1-3000 $\mu \mathrm{g} /$ $\mathrm{mL})$ induced concentration-dependent vasorelaxations $\left(\mathrm{E}_{\max }=119 \pm 14 \% ; \mathrm{n}=6\right)$ of phenylephrine tonus that were not modified after endothelium removal $\left(\mathrm{E}_{\max }=116 \pm 6 \% ; \mathrm{n}=6\right)$, after $\mathrm{KCl} 20$ $\mathrm{mM}\left(\mathrm{E}_{\max }=135 \pm 9 \% ; \mathrm{n}=6\right)$ or in rings pre-contracted with $\mathrm{KCl} 80 \mathrm{mM}\left(\mathrm{E}_{\max }=125 \pm 4 \% ; \mathrm{n}=\right.$ 6). In endothelium denuded rings, HFDE (300 or $1000 \mu \mathrm{g} / \mathrm{mL}$ ) inhibited contractions induced by $\mathrm{CaCl}_{2}$ (maximal inhibition $=25 \pm 7 \%$ and $95 \pm 1 \%$; respectively). Furthermore, HFDE promoted an additional vasorelaxation $(15 \pm 3 \% ; \mathrm{n}=7)$ after maximal response of $10 \mu \mathrm{M}$ nifedipine $(78 \pm 3 \%$; $\mathrm{n}=7$ ). In conclusion, HFDE induces vasorelaxant effect through an endothelium-independent pathway, which mostly seems to occur due inhibition of the $\mathrm{Ca}^{2+}$ influx through voltage-operated $\mathrm{Ca}^{2+}$ channels.
\end{abstract}

Keywords: Hyptis fruticosa, dichloromethane extract, vasorelaxant effect, mesenteric artery, rats.

\section{INTRODUCTION}

The use of medicinal plants for the treatment of human diseases has increased considerably worldwide. Evaluation of the effects of these plants on organs and systems has contributed to the development of the scientific basis for their therapeutic application, and also has enriched considerably the therapeutic arsenal for the treatment of a number of diseases (Elizabetsky, 1986).

Hyptis genus, Lamiaceae, is composed by four hundred species distributed at all American Continent. In Brazil, this species is mainly distributed at the central region (Harley, 1988). Various species of this genus are used in the folk medicine because of its antiinflammatory, antinociceptive, anticonvulsant and antiulcerogenic actions (Barbosa \& Ramos, 1992; Akah \& Nwambie, 1993; Kuhnt et al., 1995; Bispo et al., 2001).

Hyptis fruticosa Salzm. ex Benth., Lamiaceae, popularly known in Brazil as "alecrim-do-campo" or "alecrim-do-vaqueiro", is an aromatic sub-bush plant which 
grows up to $1.5 \mathrm{~m}$ found on the Brazilian northeastern coast. Phytochemical studies performed in our laboratory have demonstrated that leaves of this plant present tanins, terpenes, steroids and alkaloids, and absence of saponins (unpublished data). Previous pharmacological studies have demonstrated that $H$. fruticosa presented analgesic (Silva et al., 2006; Cândido, 2006; Menezes et al., 2007), larvicidal (Silva et al., 2008) and hypotensive activities (Santos et al., 2007). Thus, the aim of this work was to evaluate the vasorelaxant effect of Hyptis fruticosa dichloromethane extract (HFDE) and its action mechanism in rats.

\section{MATERIAL AND METHODS}

\section{Drugs}

The drugs used were: Acetylcholine chloride (Ach), L-phenylephrine chloride (Phe) and cremophor (a derivative of castor oil and ethylene oxide used to emulsify water-insoluble substances) (SIGMA). All compounds were dissolved in distilled water.

\section{Extraction}

Hyptis fruticosa Salzm. ex Benth., Lamiaceae, collected near São Cristóvão (S $10^{\circ} 56^{\prime}$ W $37^{\circ} 11^{\prime}$ ), Brazilian State of Sergipe, was identified by Prof. Dr. Adauto Souza Ribeiro, Botanist in the Biology Department, Universidade Federal de Sergipe. A voucher specimen was deposited in the Herbarium of the Biology Departament, Universidade Federal de Sergipe (code ${ }^{\circ}$ ASE 01137). Aerial parts of $H$. fruticosa were dried at $40^{\circ} \mathrm{C}$ in an oven with air circulation and pulverized. The powder $(500 \mathrm{~g})$ was exhaustively extracted with methanol $(1: 5 \mathrm{p} / \mathrm{v})$ by 8 dias to room temperature. After filtration, the solvent was removed under reduced pressure, yielding $78.5 \mathrm{~g}$ of the methanol extract. The HFDE was obtained from methanol extract by using the following solvents: dichloromethane, ethyl acetate and methanol yielding: $8.4 \mathrm{~g}(1.68 \%), 5.4 \mathrm{~g}$ $(1.08 \%)$ and $29.5 \mathrm{~g}(5.90 \%)$, respectively.

\section{Animals}

Male Wistar rats (200-300 g) were used in all experiments. They were housed in conditions of controlled temperature $\left(21 \pm 1{ }^{\circ} \mathrm{C}\right)$ and exposed to a $12 \mathrm{~h}$ light-dark cycle with free access to food (Purina-Brazil) and tap water. All procedures described in the present work are in agreement with Animal Research Ethics Committee from Universidade Federal de Sergipe.

\section{Solutions}

The composition of the normal Tyrode's solution used was: $\mathrm{NaCl} 158.3, \mathrm{KCl} 4.0, \mathrm{CaCl}_{2} 2 \mathrm{H}_{2} \mathrm{O} 2.0, \mathrm{NaHCO}_{3}$ $10.0, \mathrm{C}_{6} \mathrm{H}_{12} \mathrm{O}_{6} 5.6, \mathrm{MgCl}_{2} \cdot 6 \mathrm{H}_{2} \mathrm{O} 1.05$ and $\mathrm{NaH}_{2} \mathrm{PO}_{4} \mathrm{H}_{2} \mathrm{O}$
$0.42 \mathrm{mM} . \mathrm{K}^{+}$-depolarizing solutions $(\mathrm{KCl} 20,60$ and 80 $\mathrm{mM}$ ) were prepared by replacing 20,60 or $80 \mathrm{mM} \mathrm{KCl}$ in the Tyrode's solution with equimolar $\mathrm{NaCl}$, respectively and nominally without $\mathrm{Ca}^{2+}$ solution was prepared by omitting $\mathrm{CaCl}_{2}$.

\section{Tissue preparation}

Rats were euthanized by cervical dislocation and exsanguination. The superior mesenteric artery was removed, cleaned from connective tissue and fat, and sectioned in rings $(1-2 \mathrm{~mm})$, which were suspended in organ baths containing $10 \mathrm{~mL}$ of Tyrode's solution, gassed with a mixture of $95 \% \mathrm{O}_{2}$ and $5 \% \mathrm{CO}_{2}$ and maintained at $37^{\circ} \mathrm{C}$. Isometric tension was recorded under a resting tension of $0.75 \mathrm{~g}$. During the stabilization period the solution was changed every 15 min (Altura \& Altura, 1970). The isometric tension was recorded through a force transducer (Gould, Model GM2, USA) coupled to an amplifier-recorder (Gould, USA). Endothelium was removed by gently rubbing the intimal surface of the vessels. The presence of functional endothelium was assessed by the ability of acetylcholine (ACh) $(10 \mu \mathrm{M})$ to induce more than $70 \%$ relaxation of pre-contracted vessels with phenylephrine $(10 \mu \mathrm{M})$. The absence of the relaxation to ACh was taken as evidence that the vessel segments were functionally denuded of endothelium.

\section{HFDE effect on phenylephrine $(10 \mu \mathrm{M})$ induced tonus in isolated rat superior mesenteric artery rings with or without endothelium}

After the stabilization period, two successive contractions of similar magnitude were induced with 10 $\mu \mathrm{M}$ Phe in rings with or without endothelium. During the tonic phase of the third contraction, different concentrations of HFDE $(0.1 ; 0.3 ; 1 ; 3 ; 10 ; 30 ; 100 ; 300 ; 1000$ and 3000 $\mu \mathrm{g} / \mathrm{mL}$ ) were added cumulatively to the organ bath. The relaxations were measured by comparing the developed tension before and after the addition of HFDE and expressed as percentage of relaxation from induced tonus. In other set of experiments, concentration-response curves were obtained in rings without endothelium before and after to the pre-incubated with $20 \mathrm{mM}$ of $\mathrm{KCl}$.

\section{Effect of HFDE on contraction induced by KCl $80 \mathrm{mM}$ in endothelium-denude rings}

After the stabilization period, rings without endothelium were pre-contracted with $\mathrm{K}^{+}$-depolarizing solutions $(\mathrm{KCl} 80 \mathrm{mM})$ and, on the tonic phase, different concentrations of $\operatorname{HFDE}(0.1 ; 0.3 ; 1 ; 3 ; 10 ; 30 ; 100$; $300 ; 1000$ and $3000 \mu \mathrm{g} / \mathrm{mL}$ ) were added cumulatively to organ bath. The relaxations were measured as previously described. 


\section{Effect of HFDE on concentration-response curves to $\mathrm{CaCl}_{2}$ in endothelium-denuded rings}

After the stabilization period, the rings without endothelium were contracted with $\mathrm{K}^{+}$-depolarizing solution $(\mathrm{KCl} 60 \mathrm{mM})$ and washed with normal Tyrode's solution until full recovery of initial tension. After this, they were incubated with nominally without $\mathrm{Ca}^{2+}$ solution for $15 \mathrm{~min}$ and afterwards exposed to nominally without $\mathrm{Ca}^{2+}$ solution with $\mathrm{KCl}$ to $60 \mathrm{mM}$ for another $15 \mathrm{~min}$ (Goodfraind et al., 1986). Then, a first cumulative concentration-response curve to $\mathrm{CaCl}_{2}\left(3 \times 10^{-6}, 10^{-5}, 3 \times 10^{-5}, 10^{-4}, 3 \times 10^{-4}, 10^{-3}\right.$, $3 \times 10^{-3}, 10^{-2}$ and $3 \times 10^{-2} \mathrm{M}$ ) was obtained. In these same preparations, HFDE (300 or $1000 \mu \mathrm{g} / \mathrm{mL}$ ) was individually pre-incubated for $15 \mathrm{~min}$ and a second cumulative concentration-response curve to $\mathrm{CaCl}_{2}$ was obtained. This curve was compared with those obtained in the absence of HFDE and the results were expressed as percentages of the maximal response to $\mathrm{CaCl}_{2}$ alone.

\section{Effect of HFDE on maximal vasorelaxant response of nifedipine in endothelium denuded rings}

Initially, a concentration-response curve to nifedipine was performed in order to determine the concentration of maximal vasorelaxant response in endothelium-denuded rings pre-contracted with $10 \mu \mathrm{M}$ of Phe (data not shown). After this, others endotheliumdenuded rings pre-contracted with $10 \mu \mathrm{M}$ of Phe were incubated with $1000 \mu \mathrm{g} / \mathrm{mL}$ of HFDE or $10 \mu \mathrm{M}$ of nifedipine, separately. In other set of experiments, endothelium-denuded rings pre-contracted with $10 \mu \mathrm{M}$ of Phe were incubated with $10 \mu \mathrm{M}$ of nifedipine and after obtainment of the maximal vasorelaxant response, HFDE $(1000 \mu \mathrm{g} / \mathrm{mL})$ was added in organ bath. The responses to each vasorelaxant agent were statistically compared.

\section{Statistical analysis}

Values were expressed as mean \pm SEM. When appropriate, one-way ANOVA or two-way ANOVA for repeated measures, both followed by Bonferroni posttest, was performed to evaluate the significance of the differences between means. Statistically different values were detected at a significance level of 0.05 .

\section{RESULTS AND DISCUSSION}

In intact rings of rat isolated superior mesenteric artery, $\operatorname{HFDE}(0.1,0.3,1,3,10,30,100,300$ and 1000 $\mu \mathrm{g} / \mathrm{mL}$, cumulatively) induced vasorelaxation in a concentration dependent manner of tonus induced by 10 $\mu \mathrm{M}$ phenylephrine $\left(\mathrm{E}_{\max }=119 \pm 14 \% ; \mathrm{n}=6\right)($ Figure 1).

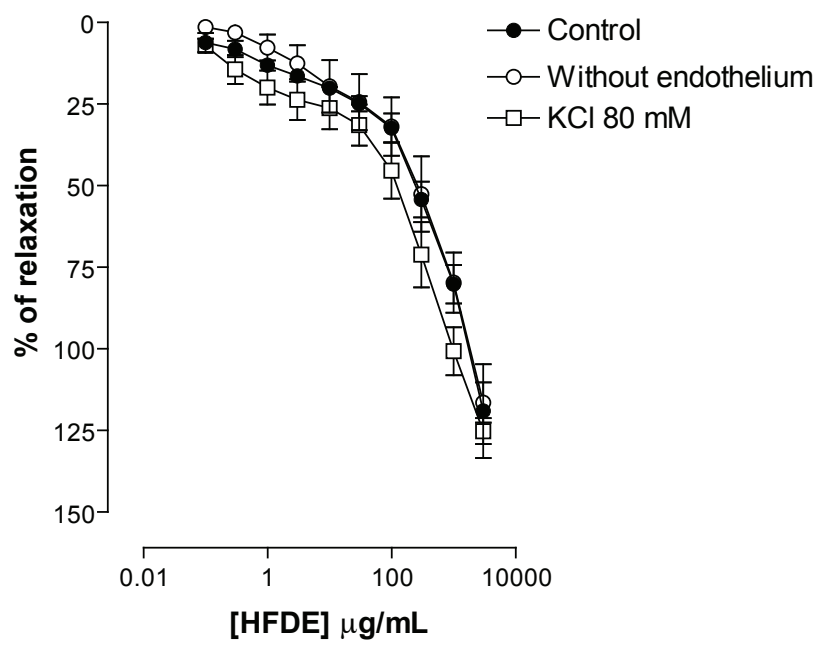

Figure 1. Concentration-response curves to $\operatorname{HFDE}(0.1 ; 0.3$; $1 ; 3 ; 10 ; 30 ; 100 ; 300 ; 1000$ and $3000 \mu \mathrm{g} / \mathrm{mL})$ in rings of rat isolated superior mesenteric artery pre-contracted with 10 $\mu \mathrm{M}$ Phe (Control), without functional endothelium (Without endothelium) and rings without endothelium pre-contracted with $\mathrm{K}^{+}$-depolarizing solutions $(\mathrm{KCl} 80 \mathrm{mM})$. Values are expressed as mean $\pm \mathrm{SEM}, \mathrm{n}=6$. The data were analyzed with repeated measures two-way ANOVA followed by Bonferroni post-test.

It is well known that the endothelium is an important regulator of the vascular tone by releasing endothelium-derived relaxing factors (Moncada et al., 1991), mainly NO and COX-derived products, such as PGI2 (Moncada et al., 1991; Furchgott \& Zawadzki, 1980). In order to investigate the participation of the endothelium in the vasorelaxant effect induced by HFDE, we performed experiments in the absence of functional endothelium. In these conditions, the vasorelaxant response induced by HFDE was not significantly changed $\left(\mathrm{E}_{\max }=116 \pm 6 \% ; \mathrm{n}=6\right)$ (Figure 1). This suggests that the presence of endothelium is not essential for relaxant response expression and that an endothelium-independent pathway is probably implicated in this effect.

Potassium channels importantly contribute to the determination and regulation of the vascular tone (Nelson \& Quayle, 1995; Jackson, 2000). The electrochemical gradient for $\mathrm{K}^{+}$ions is such that the opening of $\mathrm{K}^{+}$channels results in the diffusion of this cation out of the cells with consequent hyperpolarization. This effect closes voltageoperated $\mathrm{Ca}^{2+}$ channels and leads to vasorelaxation (Jackson, 2000). In order to investigate the involvement of $\mathrm{K}^{+}$channels in the vasorelaxant effect of HFDE, we performed experiments in the presence of $20 \mathrm{mM}$ of $\mathrm{K}^{+}$. This procedure partially prevents the efflux of $\mathrm{K}^{+}$through the membrane and, therefore inhibits the relaxations mediated by the opening of $\mathrm{K}^{+}$channels (Campbell et al., 1996). Thus, In rings without endothelium pre-contracted with Phe and incubated with $\mathrm{KCl} 20 \mathrm{mM}$, the concentrationresponse curve to HFDE was not significantly changed 
$($ Emax $=135 \pm 9 \% ; \mathrm{n}=6)($ Figure 2$)$, suggesting that $\mathrm{K}^{+}$ channels appears not to be involved in this response.

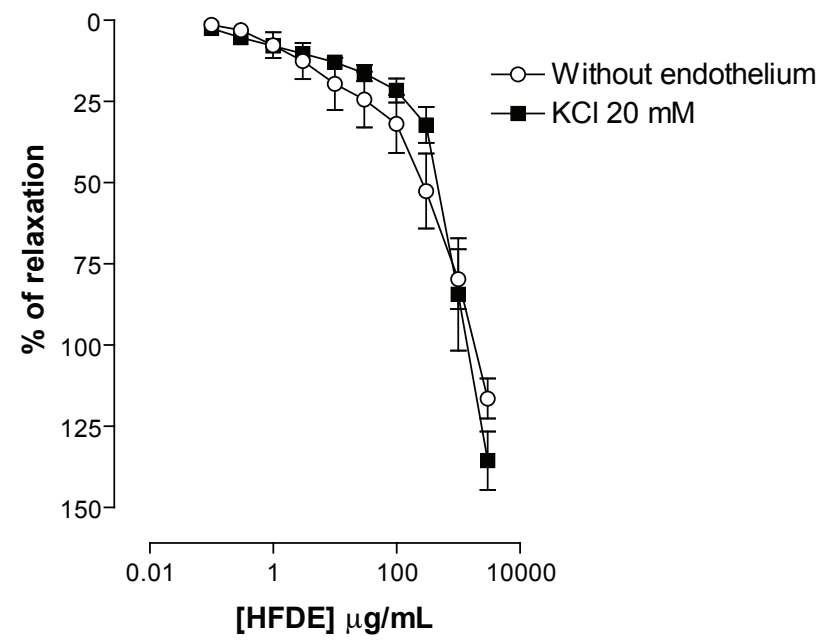

Figure 2. Concentration-response curves to $\operatorname{HFDE}(0.1 ; 0.3 ; 1 ; 3$; $10 ; 30 ; 100 ; 300 ; 1000$ and $3000 \mu \mathrm{g} / \mathrm{mL})$ in rings of rat isolated superior mesenteric artery without functional endothelium precontracted with $10 \mu \mathrm{M}$ Phe (Without endothelium), and rings without endothelium pre-contracted with $P$ he and incubated with $\mathrm{K}+$-depolarizing solutions $(\mathrm{KCl} 20 \mathrm{mM})$. Values are expressed as mean $\pm \mathrm{SEM}, \mathrm{n}=6$. The data were analyzed with repeated measures two-way ANOVA followed by Bonferroni post-test.

Calcium is the primary regulator of tension in vascular smooth muscle (Gurney, 1994). It is well known that the maintenance of smooth muscle contraction depends on $\mathrm{Ca}^{2+}$ influx from extracellular space through voltageand/or receptor-operated calcium channels (VOCCs and/ or ROCCs, respectively) (Karaki \& Weiss, 1988). It is well reported that the increase of external $\mathrm{K}^{+}$concentration (KCl $80 \mathrm{mM}$ ) induces smooth muscle contraction through VOCCs activation and subsequent calcium release from the sarcoplasmic reticulum (Karaki \& Weiss, 1988). The high $\mathrm{K}^{+}$-induced contraction is inhibited by $\mathrm{Ca}^{2+}$ channel blockers or by removal of external $\mathrm{Ca}^{2+}$ and is, therefore, entirely dependent of $\mathrm{Ca}^{2+}$ influx (Karaki \& Weiss, 1988). Thus, we evaluated the HFDE effect on endotheliumdenuded rings pre-contracted with $\mathrm{K}^{+}$-depolarizing solutions $(\mathrm{KCl} 80 \mathrm{mM})$. This set of experiments revealed that HFDE induced vasorelaxations, which were not significantly different of those observed in rings precontracted with Phe $(125 \pm 4 \% ; n=6)$ (Figure 1), suggesting that the HFDE inhibits $\mathrm{Ca}^{2+}$ influx through VOCCs.

In order to check the hypothesis above, we constructed a concentration-response curve to $\mathrm{CaCl}_{2}$ $\left(3 \times 10^{-6}, 10^{-5}, 3 \times 10^{-5}, 10^{-4}, 3 \times 10^{-4}, 10^{-3}, 3 \times 10^{-3}, 10^{-2}\right.$ and $3 \times 10^{-2} \mathrm{M}$ ) in presence of $\mathrm{K}^{+}$-depolarizing solution $(\mathrm{KCl} 60 \mathrm{mM})$, before and after incubation with HFDE in doses of 300 and $1000 \mu \mathrm{g} / \mathrm{mL}$. In these conditions, $\mathrm{CaCl}_{2}$ induced contractions in endothelium-denuded rings of rat mesenteric artery in a concentration-dependent manner that were strongly inhibited after incubation with HFDE in concentrations of 300 and $1000 \mu \mathrm{g} / \mathrm{mL}$ (maximal inhibition $=25 \pm 7 \%$ and $95 \pm 1 \% ; \mathrm{n}=6$; respectively).

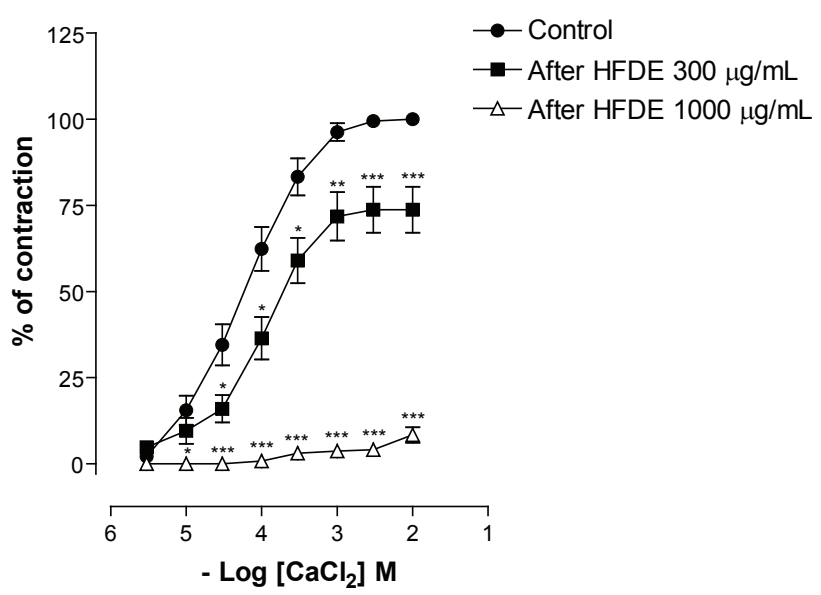

Figure 3. Concentration-response curves to $\mathrm{CaCl}_{2}\left(3 \times 10^{-6}, 10-5\right.$, $3 \times 10^{-5}, 10^{-4}, 3 \times 10^{-4}, 10^{-3}, 3 \times 10^{-3}, 10^{-2}$ and $\left.3 \times 10^{-2} \mathrm{M}\right)$ in rings of rat superior mesenteric artery, without endothelium before (control) and after pre-incubation with HFDE at concentrations of 300 and $1000 \mu \mathrm{g} / \mathrm{mL}$, separately. Values are expressed as mean \pm SEM, $n=6$. The data were analyzed with repeated measures two-way ANOVA followed by Bonferroni post-test. ${ }^{*} p<0.05, * * p<0.01$ and $* * * p<0.001$ vs control.

As reported by Chan et al. (2000), nifedipine, a L-type voltage-operated $\mathrm{Ca}^{2+}$ channel selective blocker, also inhibited the concentration-response curve to $\mathrm{CaCl}_{2}$, suggesting strongly that HFDE could be acting possibly as a calcium channel blocker.

Finally, we performed experiments in that were observed the vasorelaxation response of HFDE $(1000 \mu \mathrm{g} /$ $\mathrm{mL}$ ) and $10 \mu \mathrm{M}$ of nifedipine, separately, and the effect of HFDE $(1000 \mu \mathrm{g} / \mathrm{mL})$ after maximal vasorelaxant response induced by $10 \mu \mathrm{M}$ of nifedipine. In this condition, HFDE $(1000 \mu \mathrm{g} / \mathrm{mL})$ or nifedipine $(10 \mu \mathrm{M})$ were capable of inducing vasorelaxation of Phe tonus $\left(\mathrm{E}_{\max }=79 \pm 9\right.$ and $78 \pm 3 \% ; \mathrm{n}=6$, respectively), and HFDE $(1000 \mu \mathrm{g} / \mathrm{mL})$ induced a small but significant additional vasorelaxation effect on the maximal vasorelaxation of nifedipine (10 $\mathrm{mM})(15 \pm 3 \% ; \mathrm{n}=7)$, suggesting that HFDE appears to be acting in major part by the same pathway of the nifedipine.

However, the observation of an additional vasorelaxation after maximal response of nifedipine allow us to hypothesize that other pathway appears to be implicated in the HFDE-induced response, possibly involving intracellular calcium stores. However, further experiments are necessary to clearly elucidate this assumption.

In conclusion, these results demonstrate that the dichloromethane extract of Hyptis fruticosa Salzm. ex Benth., Lamiaceae, (HFDE) produces vasorelaxant effect in rat superior mesenteric artery through an endothelium- 
independent pathway, which appears to be due in major part to inhibition of the $\mathrm{Ca}^{2+}$ influx through voltageoperated $\mathrm{Ca}^{2+}$ channels.

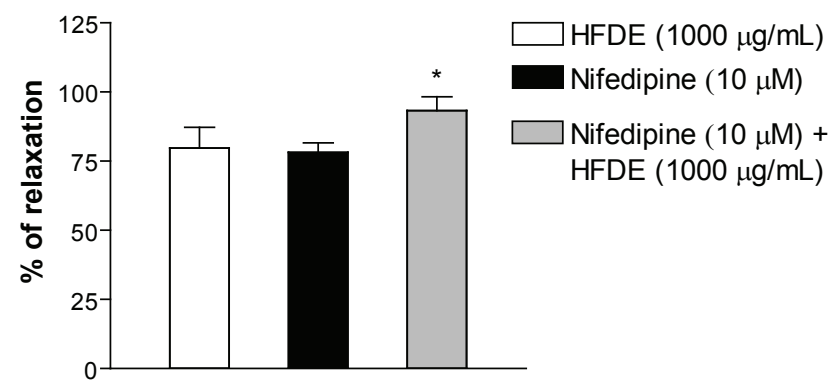

Figure 4. Vasorelaxant effect of nifedipine $(10 \mu \mathrm{M})$ before and after administration of HFDE $(1000 \mu \mathrm{g} / \mathrm{mL})$ in rings of rat isolated superior mesenteric artery without functional endothelium precontracted with $10 \mu \mathrm{M}$ Phe. Values are expressed as mean \pm SEM, $\mathrm{n}=6$. The data were analyzed with one-way ANOVA followed by Bonferroni post-test. ${ }^{*} p<0.05$ vs Nifedipine.

\section{ACKNOWLEDGEMENTS}

We thank technical assistance of Mr. Osvaldo Andrade Santos. This work was supported by grants from CNPq, CAPES, FAPITEC-SE, Ministério da Saúde, SES/ SE, Brazil.

\section{REFERENCES}

Akah PA, Nwambie AI 1993. Nigerian plants with anti-convulsant property. Fitoterapia 64: 42-44.

Altura BM, Altura BT 1970. Differential effects of substrate depletion on drug-induced contractions of rabbit aorta. Am J Physiol 219: 1698-1705.

Barbosa PPP, Ramos CP 1992. Studies on the antiulcerogenic activity of the essential oil of Hyptis mutabilis Briq in rats. Phytotherapy 6: 114-115.

Bispo MD, Mourão RHV, Franzotti EM, Bomfim KBR, ArrigoniBlank MF, Moreno MPN, Machioro M, Antoniolli AR 2001. Antinociceptive and antiedematogenic effects of the aqueous extract of Hyptis pectinata leaves in experimental animals. J Ethnopharmacol 76: 81-86.

Campbell WB, Gebremedhin D, Prait PF, Herder DR 1996. Identification of epoxyeicosatrienoic acids as endothelium-derived hyperpolarizing factors. Circ Res 78: 415-423.

Cândido EAF 2006. Caracterização parcial dos efeitos do extrato hidroalcoólico das folhas da Hyptis fruticosa no sistema nervoso central de camundongos. São Cristóvão, $75 \mathrm{p}$. Dissertação de Mestrado, Programa de Pós-graduação em Ciências da Saúde, Universidade Federal de Sergipe.

Chan W, Yao X, Ko W, Huang Y 2000. Nitric oxide mediated endothelium-dependent relaxation induced by glibenclamide in rat isolated aorta. Cardiovasc Res 46: 180-187.

Elizabetsky E 1986. New directions in ethnopharmacology. $J$ Ethnobiol 6: 121-121.
Furchgott RF, Zawadzki JV 1980. The obligatory role of endothelial cells in the relaxation of arterial smooth muscle by acetylcholine. Nature 288: 373-376.

Goodfraind T, Miller R, Wibo M 1986. Calcium antagonism and calcium entry blockade. Pharmacol Rev 38: 321-416.

Gurney AM 1994. Mechanisms of drug-induced vasodilatation. $J$ Pharm Pharmacol 46: 242-251.

Harley RM 1988. Revision of generic limits in Hyptis Jacq (Labiatae) and its allies. Bot J Linn Soc 98: 87-95.

Jackson WF 2000. Ion channels and vascular tone. Hypertension 35: 173-178.

Karaki H, Weiss GB 1988. Calcium release in smooth muscle. Life Sci 42: 111-122.

Kuhnt M, Probstle A, Rimpler H, Bauer R, Heinrich M 1995. Biological and pharmacological activities and further constituents of Hyptis verticillata. Planta Med 61: 227232.

Menezes IAC, Marques MS, Santos TC, Dias KS, Silva ABL, Mello ICM, Lisboa ACCD, Alves PB, Cavalcanti SCH, Marçal RM, Antoniolli AR 2007. Antinociceptive effect and acute toxicity of the essential oil of Hyptis fruticosa in mice. Fitoterapia 78: 192-195.

Moncada S, Palmer RMJ, Higgs EA 1991. Nitric Oxide: Physiology, pathophysiology and pharmacology. Pharmacol Rev 43: 109-142.

Nelson MT, Quayle JM 1995. Physiological roles and properties of potassium channels in arterial smooth muscle. Am J Physiol 268: C799-C822.

Santos MRV, Carvalho AA, Medeiros IA, Alves PB, Marchioro M, Antoniolli AR 2007. Cardiovascular effects of Hyptis fruticosa essential oil in rats. Fitoterapia 78: 186-191.

Silva ABL, Dias KS, Marques MS, Menezes IAC, Santos TC, Mello ICM, Lisboa ACCD Cavalcanti SCH, Marçal RM, Antoniolli AR 2006. Evaluation of the analgesic effect and acute toxicity of the aqueous extract of Hyptis fruticosa (Salmz. ex Benth.)". Rev Bras J Pharmacogn 16: 475-479.

Silva WJ, Dória GAA, Maia RT, Nunes RS, Carvalho GA, Blank PB, Marçal RM, Cavalcanti SCH 2008. Effects of essential oils on Aedes aegypti larvae: Alternatives to environmentally safe insecticides. Bioresource Technol 99: 3251-3255. 